\title{
ІНДИВІДУАЛІЗАЦІЯ ХІРУРГІЧНОГО ЛІКУВАННЯ ХВОРИХ НА РАК ШЛУНКА
}

\author{
С. І. Кіркілевський ${ }^{1}$, В. Г. Дубініна ${ }^{3}$, О. В. Лукьянчук²,3, А. О. Машуков ${ }^{1,2,3}$
}

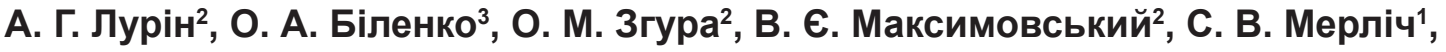
Д. В. Раціборський ${ }^{1}$, І. В. Шілін ${ }^{1}$

${ }^{1}$ Національний інститут раку МОЗ України, м. Київ,

${ }^{2}$ Одеський обласний онкологічний диспансер,

${ }^{3}$ Одеський національний медичний університет

\section{INDIVIDUALIZATION OF SURGICAL TREATMENT OF PATIENTS, SUFFERING GASTRIC CANCER}

S. I. Kirkilevskyi' ${ }^{1}$, V. G. Dubinina ${ }^{3}$, O. V. Lukyanchuk ${ }^{2,3}$, A. O. Mashukov ${ }^{1,2,3}$, A. G. Lurin'2, O. A. Bilenko ${ }^{3}$, O. M. Zgura ${ }^{2}$, V. E. Maxymovskyï, S. V. Merlich ${ }^{1}$, D. V. Ratsiborskyi ${ }^{1}$, I. V. Shilin ${ }^{1}$

${ }^{1}$ National Cancer Institute, Kyiv,

${ }^{2}$ Odessa Regional Oncological Dispensary,

${ }^{3}$ Odessa National Medical University

\section{Реферат}

Проведений кореляційний аналіз молекулярних і морфологічних чинників злоякісності і ефективності розширених і комбінованих операцій з приводу раку шлунка (РШ). Хворим здійснювали розширену лімфодисекцію (ЛДС), а також мультиорганну резекцію (MP), компонентом якої була селективна перитонеоектомія. За місцево-поширеного РШ втручання доповнювали внутрішньочеревною гіпертермічною хіміоперфузією (ВЧГТХП). Доведено ефективність поєднаного застосування розширеної ЛДС та МР 3 приводу РШ. Проаналізовані показники виживання хворих на основі аналізу вмісту молекулярних маркерів (VEGFR, p53, Her2, Ki-67) і стандартних гістологічних маркерів (стадія, ступінь диференціювання пухлини тощо). Критерієм ефективності лікування визнані показники виживання хворих на РШ.

Ключові слова: рак шлунка; мультиорганна резекція; перитонеоектомія; розширена лімфодисекція, онкобілкі.

Abstract

Correlational analysis of molecular and morphological malignant factors and efficacy of extended and combined operations for gastric cancer (GC) was conducted. Extended lymphodissection and multiorgan resection (MR), including selective peritoneoectomy, was performed. For locally-spread GC the intervention was added by intraabdominal hypertermal chemoperfusion. Efficacy of combined application of extended lymphodissection and MR for GC was proved. The survival indices, basing on analysis of the molecular markers content (VEGFR, p53, Her2, Ki-67) and the standard histological markers (stage, degree of tumoral differentiation etc) were analyzed for these patients. Survival indices in the GC patients are considered the criteria of the treatment efficacy.

Keywords: gastric cancer; multiorgan resection; peritoneoectomy; extended lymphodissection, oncoproteins.

За період 1995 - 2015 рр. у відділенні абдомінальної онкології Одеського обласного онкологічного диспансера радикальні операції на шлунку виконані у 1733 хворих, 3 них у 846 - гастректомія, у 887 - дистальна субтотальна резекція шлунка 3 приводу верифікованого за даними гістологічного дослідження РШ. Кількість операцій, які щороку виконували в клініці, становила: гастректомії - від 19 (у 1997 р.) до 79 (у 2005 р.); дистальної субтотальної резекції - від 27 (у 1995 р.) до 75 (у 2005 р.). Летальність становила $1,2 \%$, операбельність - 84\%. 3 огляду на значну хіміорадіорезистентність злоякісних епітеліальних пухлин шлунка, хірургічні методи відіграють провідну роль у комплексному лікуван- ні хворих з приводу РШ. Важливе значення має виконання розширених та комбінованих онкохірургічних втручань, які доповнюють ад'ювантною хіміотерапією. За місцевопоширеного РШ як ад'ювантне лікування використовують інтра- або післяопераційне введення підігрітого до $42^{\circ} \mathrm{C}$ розчину хіміопрепарату - ВЧГТХП. Численні фактори впливають на тривалість життя лікованих пацієнтів. Сьогодні немає інструментів або приладів, які б дозволяли визначити тривалість життя конкретної людини. Проте, спираючись на результати математичного аналізу відразу багатьох факторів, можна прогнозувати очікувану тривалість життя хворого на РШ. Завданням дослідження був аналіз подібних тен- денцій, коли, знаючи вік пацієнта, стадію захворювання, ступінь біологічної агресивності пухлини, можна скласти орієнтовний прогноз тривалості життя після операції. При цьому не брали до уваги інші причини смерті, не пов'язані з онкологічним захворюванням (інфаркт, інсульт, іншi).

Новизною дослідження $\epsilon$, поперше, висічення очеревини, ураженої пухлинним канцероматозом, як компоненту МР при РШ; по-друге, виконання розширеної, зокрема, D2+ ЛДС; по-трете, застосування ВЧГТХП; по-четверте, для оцінки біологічної агресивності злоякісної пухлини аналізували молекулярні критерії агресивності, зокрема, вміст VEGFR, p53, Her2, Ki-67. 


\section{МАТЕРІАЛИ I МЕТОДИ ДОСЛІДЖЕННЯ}

3 приводу РШ в період 2007 2013 рр. оперований 221 хворий, віком у середньому $(60,88 \pm 10,5)$ року, чоловіків - 180, жінок - 41. У 143 хворих виконана гастректомія, у 78 - дистальна субтотальна резекція шлунка. Резекцію шлунка здійснювали за методикою Бондаря 3 формуванням термінолатерального петльового муфтоподібного позадуободового езофагоєюноанастомозу 3 міжкишковим співустям за Брауном. Дистальну субтотальну резекцію завершували, як правило, формуванням позадуободового гастроентероанастомозу за ГофмейстеромФінстерером. Летальність становила 1,2\%, операбельність - 84\%. Аналізували показники виживання хворих залежно від стадії пухлини та виду операціі.

МР характеризувалася частковим або повним видаленням кількох органів. Внутрішньостінкове поширення на стравохід відзначене у 31 $(16,49 \%)$ хворого, що потребувало у 28 з них резекції піддіафрагмального сегмента (за Савіних); у 3 - виконана операція Осава-Гарлока з резекцією внутрішньодіафрагмального сегмента стравоходу. Поширення пухлини на дванадцятипалу кишку у 2 (1,06\%) хворих морфолог класифікував за найбільшою глибиною інвазіі. Резекція хвоста підшлункової залози виконана у 74 (39,36\%) хворих, справжнє проростання в підшлункову залозу за даними гістологічного дослідження встановлене у 5 (2,66\%) 3 них, атипова резекція печінки виконана у 9 (4,79\%), анатомічна резекція - у 3 (1,59\%). Спленектомія здійснена у 153 (81,38\%) хворих, як правило, $з$ принципових міркувань як компонент ЛДС D1+ і вище. У 5 (2,66\%) хворих виявлене метастатичне ураження капсули селезінки, у 3 (1,59\%) - виконана дисекція воріт селезінки як компонент спленозберігальної операції. У 4 хворих виконана селективна перитонеоектомія - видалення пристінкової або нутрощевої очеревини за умови іiі ураження канцероматозом. Перспективним вважали виконання перитонеоектомії за індексу РСІ (перитонеальний індекс канцероматозу) менше 10 при РШ.

Хворі розподілені на чотири групи залежно від виду розширених і

Тривалість життя залежно від стадії та виду операції (7-й перегляд класифікації TNM)

\begin{tabular}{|c|c|c|c|}
\hline $\begin{array}{c}\text { Стадія } \\
\text { захворювання }\end{array}$ & Операція & $\begin{array}{l}\text { Тривалість життя у } \\
\text { середньому, міс }\end{array}$ & $\begin{array}{c}\text { Тривалість життя залежно } \\
\text { від виду лікування, міс }\end{array}$ \\
\hline \multirow{3}{*}{ IA } & Розширена МР & \multirow{3}{*}{48} & Немає даних \\
\hline & D2 лДС & & 48 \\
\hline & Стандартна & & Немає даних \\
\hline \multirow{3}{*}{ IB } & Розширена МР & \multirow{3}{*}{23,5} & 24,7 \\
\hline & D2 лДС & & 21,8 \\
\hline & Стандартна & & 24 \\
\hline \multirow{3}{*}{ II } & Розширена МР & \multirow{3}{*}{34,1} & 48 \\
\hline & D2 лДС & & 20,3 \\
\hline & Стандартна & & 34 \\
\hline \multirow{3}{*}{ IIIA } & Розширена МР & \multirow{3}{*}{26,2} & 34,5 \\
\hline & D2 лДС & & 28,5 \\
\hline & Стандартна & & 15,6 \\
\hline \multirow{3}{*}{ IIIB } & Розширена МР & \multirow{3}{*}{27,5} & Немає даних \\
\hline & D2 ЛДС & & 15 \\
\hline & Стандартна & & 40 \\
\hline \multirow{3}{*}{ IV } & Розширена МР & \multirow{3}{*}{20,75} & 22,3 \\
\hline & D2 лДС & & 20,4 \\
\hline & Стандартна & & 21,1 \\
\hline
\end{tabular}

комбінованих оперативних втручань: поєднання D2 ЛДС і MP - у 26 хворих, тільки D2 ЛДС без MP - у 36, поєднання D1 ЛДС і MP - у 74, тільки D1 ЛДС без MP - у 85. Дослідження одноцентрове, ретроспективне. Тривалість життя хворих наведена у таблиці.

Процедуру ВЧГТХП проводили за допомогою апарата Performer LRT. Це багатофункціональна система для здійснення місцевої локальної спеціалізованої хіміотерапії, орієнтована на підтримку кількох режимів терапії, основана на екстракорпоральному циркулювання крові / рідини. Хіміотерапевтичні препарати високо токсичні, ї використання у високій концентрації супроводжується побічними реакціями. Локальна регіонарна хіміотерапія забезпечує набагато більш високу цільову концентрацію у патологічному вогнищі; проте, препарати мають бути захищені від швидкого вимивання з зони їх локальної активності. Циркуляторні параметри (температура, об'єм, швидкість інфузіі) легко відкоригувати і моніторувати в онлайн режимі.

ВЧГТХП передбачає перфузування черевної порожнини хіміотерапевтичним агентом (як правило, цисплатин або мітоміцин С) при температурі $42,5{ }^{\circ} \mathrm{C}$, усередненій швидкості потоку 800-900 мл/ хв протягом 60 - 90 хв. Лікування призначають після циторедуктивного хірургічного втручання 3 приводу перитонеального канцероматозу або саркоматозу, спричиненого гастроінтестинальною карциномою або карциномою яєчників, псевдоміксомою, перитонеальною мезотеліомою. Можливими режимами є ізольована гіпертермія кінцівок (температура $41,5^{\circ} \mathrm{C}, 60-90$ хв) і гемофільтрація (нормотермія, $20 \mathrm{xв).}$ Після хірургічного видалення якомога більшого обсягу тканини пухлини 5 силіконових трубок вводять у черевну порожнину; температурні датчики розташовують в черевній порожнині вище брижі ободової кишки і в порожнині таза, на операційну рану накладають остаточні шви. Застосовують дві помпи (нагнітають і евакуюють рідину з черевної порожнини), охолоджувач і стерильний закритий контур.

Після досягнення інтраабдомінальної температури, як мінімум, 41 ${ }^{\circ} \mathrm{C}$, мітоміцин С 325 мг/мл, цисплатин 100 мг/мл розчиняють в 5000 мл перфузату, циркулюючого зі швидкістю 700 - 800 мл хв протягом 60 хв. Середній об'єм перфузату, що міститься в черевній порожнині, щомиті становить близько 3000 мл. Інтраабдомінальна температура 41 - $43{ }^{\circ} \mathrm{C}$. Тривалість фаз охолодження черевної порожнини і промивання від хіміопрепаратів максимально 5 10 хв. Пацієнта переводять на 1 добу 
в реанімаційне відділення для проведення інтенсивної терапії та спостереження. Всім пацієнтам інтраопераційно визначали індекс перитонеального канцероматозу, а також індекс повноти циторедукції.

\section{РЕЗУЛЬТАТИ}

Хірург завжди виконує саме той обсяг оперативного втручання, що ефективний в конкретній ситуації та ефективний у конкретного хворого. 3 цією метою проводять передопераційне обстеження, що дозволяє оцінити поширення пухлини (рентгенологічне, ендоскопічне дослідження, КТ, МРТ, ПЕТ), тяжкість супутніх захворювань, наявність ускладнень пухлинного процесу, показники лабораторних (загальноклінічні аналізи, онкомаркери) і інструментальних (ЕКГ, ехокардіоскопія) досліджень. Додатковими методами оцінки клінічної ситуації є дані передопераційної біопсії пухлини, цитологічних, гістологічних, а також імуногістохімічних досліджень. Ступінь диференціювання не змінює уявлення хірурга про ситуацію в цілому, проте, дає підстави виконати гастректомію з приводу раку антрального відділу шлунка, а не субтотальную резекцію органа. Визначення вмісту онкобілків VEGFR, p53, Her2 дозволить коригувати хірургічну тактику, особливо щодо розширення обсягу операції. Так, ми досліджували не всі фракції маркера неоангіогенезу VEGFR, а лише VEGFR-C, що відображає схильність пухлини до процесингу нових лімфатичних судин - неолімфангіогенезу.

\section{ОБГОВОРЕННЯ}

Хірургічна чінність маркерів. Персоніфікація хірургічного лікування основана на тому, що мікросателітно-нестабільні (MSI) пухлини низькодиференційовані, проте, як правило, характеризуються сприятливим перебігом захворювання. Проте, високомікросателітно-нестабільним (MSI-high) пухлинам притаманна відносно низька частота рецидивів після хірургічного втручання [1, 2].

Найгірший прогноз виживання становить «потрійний негативний» РШ, по аналогії з такою самою формою раку грудної залози. Він характеризувався відсутністю неоангіо- генезу, експресії білка ТР53 і реакції на імуногістохімічні (IГX) барвники білка c-erbB2.

Особливістю, виявленою під час аналізу, було те, що пухлини при поєднанні маркерів VEGFR - p53 Her2 + Ki-67 були високодиференційованими, без проростання сусідніх структур, екзофітного росту, без ознак агресивності. Тобто, те, що позначають як локальні форми, перспективні щодо віддалених показників виживання навіть в локорегіонарній стадії. Проте, показники загального виживання хворих низькі. Це гістологічно «хороший» рак 3 «поганим» ІГХ і, відповідно, прогнозом.

У деяких хворих на РШ виконання МР впливало на показники виживання у пізні строки спостереження - після 100 міс. Основною особливістю пухлин групи VEGFR - p53 + Her2 - Ki-67+ була відсутність метастазів у регіонарних лімфатичних вузлах навіть за наявності пухлини Т4. У цій групі були більш ефективні комбіновані, а не розширені операції. Звертає увагу ще одна особливість: відсутність периневральної інвазії і велика частота екзофітних форм росту пухлини.

Наведені критерії дозволяють прогнозувати значну ефективність виконання з приводу MSI-нестабільного РШ МР; в основному відсутність метастазів в регіонарних лімфатичних вузлах, а також потенціалу «прихованої» генералізації, наприклад, по периневральних щілинах.

Лікувальна цінність маркерів. Експресію Ki67 в літературі пов'язують 3 чутливістю до хіміотерапії з використанням доцетакселу [3]. Висока експресія р53 свідчить про перспективність проведення хіміотерапії, незалежно від схеми терапії [4, 5]. Her-2neu позиціонуеться не тільки як фактор чутливості до терапії з використанням трастузумабу, а й епірубіцину, доксорубіцину [6], ліпосомального доскорубіцину. Досі не увійшов в класифікацію РШ BRCA-асоційований РШ. Наявність ампліфікації цього гена при РШ означає резистентність до хіміотерапевтичних режимів на основі таксанов [7] і антрациклінів і чутливості до мітоміцину C [8], цисплатину і PARP-інгібіторів (полі-АДФ-рибоза-полімераза інгібітори) [9], пер- спективність імунотерапіі [7]. Her2neu позиціонується не тільки як фактор чутливості до терапії з використанням трастузумабу, а й до епірубіцину, доксорубіцину [6], ліпосомального доскорубіцину.

Методи обчислення показників виживання можуть бути використані хірургами і хіміотерапевтами для персоніфікації хіміотерапевтичного (her2 / new, VEGFR) і індивідуалізаціі хірургічного лікування РШ: інвазія в стінку, вік хворого, ураження лімфатичних вузлів, розміри пухлини, ступінь злоякісності (G) і біоагресивності (р53).

Таким чином, вдається проаналізувати вплив різних онкобілків на біологічну схильність пухлини залучатися до власного мікросудинного оточення, створювати нові судини, проникати в них, утворювати пухлинні емболи і циркулюючі пухлинні комплекси.

Для раку різної локалізації існує конкретна інформація щодо показників виживання пацієнтів за стадіями захворювання. $E$ істотна потреба володіння подібною інформацією для більш вузьких клінічних ситуацій (кількість уражених лімфатичних вузлів, обсяг пухлини, виміряний за даними КТ, тощо). Мають існувати рішення, які можуть бути використані як консультативна інформація для хворого, його родичів, планування кількості курсів хіміотерапії, агресивності комплексного лікування, з огляду на високу вартість хіміотерапії, тощо.

У майбутньому, з появою більшої кількості клінічних даних, з'явиться білыше можливостей індивідуалізації хірургічного та комплексного лікування хворих з приводу РШ. Наприклад, за деяких біологічних форм будуть застосовувати більш розширену ЛДС, за інших - комбіновані і мультивісцеральні втручання, за третіх - ї поєднання.

Такий індівідуалізований підхід дозволить зменшити обсяг роботи хірурга, більш важливе значення матимуть ефективні протипухлинні засоби.

\section{ВИСНОВКИ}

1. Виконання розширених операцій з застосуванням D2, D2+, D3 ЛДС не супроводжувалося збільшенням летальності та частоти ускладнень 
в найближчому післяопераційному періоді.

2. Перитонеоектомія в поєднанні $з$ виконанням ВЧГТХП - єдина сьогодні можливість адекватного контролю локорегіонарних форм PU.

\section{REFERENCES}

1. Popat S, Hubner R, Houlston RS. Systematic review of microsatellite instability and colorectal cancer prognosis. J Clin Oncol. 2005;23:609-18.

2. Guastadisegni C, Colafranceschi M, Ottini L, Dogliotti E. Microsatellite instability as a marker of prognosis and response to therapy: a meta-analysis of colorectal cancer survival data. Eur $\mathrm{J}$ Cancer 2010;46:2788-98. doi: 10.1016/j.ejca.2010.05.009. [PubMed] [Cross Ref].

3. Penault-Llorca F, André F, Sagan C, Lacroix-Triki M, Denoux Y, Verriele $\mathrm{V}$, et al. Ki67 expression and docetaxel efficacy in patients with estrogen receptor-positive breast cancer. J Clin Oncol. 2009 Jun 10;27(17):2809-15. doi: 10.1200/JCO.2008.18.2808. Epub 2009 Apr 20.

4. Coppedè F, Lopomo A, Spisni R, Migliore L. Genetic and epigenetic biomarkers for diagnosis, prognosis and treatment of colorectal cancer. World J Gastroenterol. 2014 Jan 28;20(4):943-56. Published online 2014 Jan 28. doi: 10.3748/wjg.v20.i4.943.

5. Tzeng ST, Tsai MH, Chen CL, Lee JX, Jao TM, Yu SL, et al. NDST4 is a novel candidate tumor suppressor gene at chromosome $4 \mathrm{q} 26$ and its genetic loss predicts adverse prognosis in colorectal cancer PLoSOne. 2013;8: e67040 [PMID: 23825612 DOI: 10.1371/journal. pone.0067040]. сію факторів VEGFR, p53, Her2, Ki67. 6oliterni A, Ménard S, Valagussa P, Biganzoli E, Boracchi P, Balsari $A$, et al. HER2 overexpression and doxorubicin in adjuvant chemotherapy for resectable breast cancer. JCO. 2003 February 1;21(3):458-62. doi: 10.1200/JCO.2003.04.021. (полнотекстовая http://jco.ascopubs.org/content/21/3/458.full).

7. Nanda R, Chow LQ, Dees EC, Berger R, Gupta S, Geva R, et al. Pembrolizumab in patients with advanced triple-negative breast cancer: Phase Ib KEYNOTE-012 Study. J Clin Oncol. 2016 Jul 20;34(21):2460-7. doi: 10.1200/JCO.2015.64.8931. Epub 2016 May 2.

8. Moiseyenko VM, Chubenko VA, Moiseyenko FV, Zhabina AS, Gorodnova TV, Komarov YI, et al. Evidence for clinical efficacy of mitomycin $\mathrm{C}$ in heavily pretreated ovarian cancer patients carrying germ-line BRCA1 mutation. Med Oncol. 2014 Oct;31(10):199. doi: 10.1007/s12032-014-0199-x. Epub 2014 Sep 4.

9. Munroe M, Kolesar J. Olaparib for the treatment of BRCA-mutated advanced ovarian cancer. Am J Health Syst Pharm. $2016 \mathrm{Ju}$ 15;73(14):1037-41 